\title{
Вплив програми фізичної терапії та ерготерапії на стан когнітивних функцій в осіб з правопівкульним ішемічним інсультом, ускладненим неглектом
}

\author{
УДК 616.831-005-036.11-036.868-08 \\ О. А. Дуло, Ю. М. Дідо \\ Ужгородський національний університет, Ужгород, Україна
}

\begin{abstract}
Резюме. Однією з найважливіших і при цьому невирішених проблем під час проведення реабілітації пацієнтів після інсульту є відновлення осіб, які страждають на синдром ігнорування (неглекту). Мета. Визначити та дослідити особливості порушення когнітивних функцій у осіб з правопівкульним ішемічним інсультом, ускладненим неглектом, та їх зміни під впливом програми фізичної терапії та ерготерапії. Методи. Аналіз наукової літератури порівняння, методи математичної статистики. Результати. Синдром неглекту - це порушення сприйняття простору і схеми свого тіла, виражений в ігноруванні половини тіла і/чи простору з боку, протилежного ураженій півкулі головного мозку, а також інформації, що надходить з цього боку. Внаслідок неглекту у пацієнтів за тестом МоСА було виявлено проблеми із зорово-конструктивними виконавчими навичками, пам'яттю, увагою, абстракцією та орієнтацією. Результати визначення важкості неглекту свідчили про мету фізичної терапії та ерготерапії осіб, які перенесли інсульт. Програма реабілітації була спрямована на відновлення рухових та когнітивних навичок, включала подвійні завдання. Найбільшу увагу приділяли верхній кінцівці. Під впливом запропонованої програми наприкінці курсу отримано позитивні зміни порівняно з початковими результатами. Незважаючи на протиріччя, використання подвійних завдань $є$ доцільним у програмах фізичної терапії та ерготерапії осіб, які перенесли інсульт.
\end{abstract}

Ключові слова: інсульт, неглект, когнітивні порушення, фізична терапія, ерготерапія, подвійні завдання.

The influence of the physical therapy and occupational therapy program on cognitive functions in persons with right-hemispheric inchemic stroke complicated by neglect

\section{O. A. Dulo, I. M. Dido}

Uzhhorod National University, Uzhhorod, Ukraine

Abstract. One of the most important and unresolved issues in the rehabilitation of patients after stroke is the recovery of those suffering from the syndrome of neglect. Objective. Identify and investigate the features of cognitive impairment in persons with right hemispheric ischemic stroke complicated by neglect and their changes under the influence of physical therapy and ergotherapy. Methods. Analysis of scientific literature, comparison, methods of mathematical statistics. Results. Neglect syndrome is a violation of the perception of space and the scheme of your body, expressed in ignoring half of the body and/or space on the side opposite to the affected hemisphere of the brain, as well as information coming from this side. As a result of neglect, the MoCA test revealed problems with visual-constructive performance skills, memory, attention, abstraction, and orientation. The results of determining the severity of neglect indicated the purpose of physical therapy and ergotherapy for stroke patients. The rehabilitation program was aimed at restoring motor and cognitive skills, including double tasks. The greatest attention was paid to the upper limb. Under the influence of the proposed program the positive changes compared to the initial results were obtained at the end of the course. Despite the controversy, the use of double tasks is appropriate in physical therapy and ergotherapy programs for stroke survivors.

Keywords: stroke, neglect, cognitive disorders, physical therapy, ergotherapy, double tasks. 
Постановка проблеми. Конвенція $\mathrm{OOH}$ про права осіб з інвалідністю (UNCRPD) включає право на реабілітацію для всіх пацієнтів, які мають фрункціональні порушення [29], але звіт SAFE 2017 р. про інсульт у Європі [27] ясно показав, що доступ до реабілітації дуже різний у країнах Європи. У тому самому році ВООЗ звернулася із закликом до дій «Реабілітація 2030», щоб вирішити проблему наявності значних потреб у реабілітації в усьому світі і суттєвої апатії до цих потреб, продемонстровану багатьма урядами $[20,30]$.

Однією 3 найважливіших і при цьому невирішених проблем під час проведення реабілітації пацієнтів після інсульту $є$ відновлення осіб, які страждають на синдром ігнорування (неглекту). Розрахункова поширеність його після одностороннього інсульту становить 30 \% [6]. Неглект частіше зустрічається після ураження правої півкулі головного мозку. Зменшення поширеності неглекту з часом очевидне, але точне його проявлення на пізніх стадіях, на жаль, неможливо оцінити $[7,8]$.

На думку ряду дослідників, неглект $є$ одним з важливих фракторів, які стримують відновлення неврологічних фрункцій $[3,4]$. Просторове ігнорування при цьому синдромі асоціюється 3 мінімальним відновленням рухових, чутливих, координаційних та когнітивних функцій, а також 3 низьким рівнем побутової адаптації. Простороворухові помилки впливають на здатність виконувати повсякденну діяльність у перші дні та тижні після інсульту [5]. Синдром ігнорування має негативний вплив на рівні побутової адаптації у пацієнтів з невеликим руховим дефіцитом (при більш виражених рухових порушеннях ступінь впливу даного синдрому на здатність до самообслуговування мінімальний) [22].

У багатьох пацієнтів не ідентифікують просторове ігнорування, і тому вони не отримують адекватних реабілітаційних послуг [6]. A. MenonNair et al. [18] проводили ретроспективне дослідження медичних карток з 10 випадково обраних лікарень гострої допомоги в Онтаріо (Канада). Оцінювали поширеність, терміни та частоту використання стандартизованих та нестандартизованих оцінок для виявлення одностороннього просторового ігнорування у пацієнтів у гострому періоді інсульту. 38 \% осіб отримали ту чи іншу фрорму одностороннього оцінювання просторового ігнорування. Лише $13 \%$ оцінювали за допомогою стандартизованої оцінки, і з них - $4 \%$ протягом 48 год. після інсульту або протягом 48 год. після того, як пацієнт прийшов до тями, як рекомендують настанови клінічної практики щодо інсульту. E. Esposito [13] вважає, що ви- користання багаторазового оцінювання для виявлення неглекту $\epsilon$ кращим, ніж використання одноразового критерію.

Однак навіть після виявлення неглекту у пацієнтів після інсульту досі немає єдиної думки щодо прийняття рішення про лікування та реабілітацію.

Для визначення найбільш ефективних методів відновлення стану пацієнтів з інсультом P. Chen [9] було проведено дослідження 3 використанням анонімного опитування в мережі Інтернет у 23 різних країнах. До процедури опитування було залучено 127 фрахівців із семи дисциплін (ерготерапія, фрізична терапія, сестринська справа, мовленнєва терапія, неврологія, фрізична та реабілітаційна медицина, психологія або нейропсихологія). Обрані експерти включили візуальне сканування простору, активацію кінцівок, призматичну адаптацію та постійне підтримання уваги до п'ятірки найкращих. Останніми дослідженнями виявлено, що специфрічні для кінцівок або специфрічні для напрямку переміщень рухові аномалії, що виникають при неглекті, також добре відновлюються за допомогою призматичної адаптації [12, 14, 15, 24].

На жаль, в Україні немає практики використання призматичної адаптації, тому одним з методів впливу у цьому дослідженні було обрано подвійні завдання, оскільки вкрай важливою $\epsilon$ розробка заходів фрізичної терапії та ерготерапії 3 метою цілеспрямовано впливати на незалежність у повсякденному житті, покращення якості життя та підвищення фрункціональних можливостей осіб з інсультом.

Роботу виконано відповідно до наукової теми кафедри фрізичної терапії ДВНЗ «Ужгородський національний університет» на 2016-2020 рр. «Відновлення психофрізичного потенціалу організму осіб різного віку і статі, які мають відхилення у стані здоров'я, з застосуванням новітніх реабілітаційних технологій» (номер держреєстрації 0116U003326).

Мета дослідження - визначити та дослідити особливості порушення когнітивних функкцій в осіб з правопівкульним ішемічним інсультом, ускладненим неглектом, та їх зміни під впливом програми фрізичної терапії та ерготерапії.

Методи дослідження: аналіз наукової літератури, порівняння оцінювання, методи математичної статистики.

Результати дослідження та їх обговорення. Порівняння ефективності програми фрізичної терапії та ерготерапії здійснювали за допомогою показників відновлення когнітивних фоункцій за шкалою МоСА. 
Для математичної обробки числових даних дослідження використовували прикладні програмами Statistica 7.0 та IBM SPSS Statistics 21. Математичну обробку числових даних проводили за допомогою методів варіаційної статистики. Аналіз відповідності виду розподілу кількісних показників закону нормального розподілу перевіряли за критерієм Шапіро-Уілка (W).

Для кількісних показників, які мали нормальний розподіл, визначали середнє значення $(\bar{x})$ та середньоквадратичне відхилення (S). Для кількісних показників, які мали розподіл, що не відповідав нормальному, визначали медіану (Ме) та нижній і верхній квартилі $(25 \% ; 75 \%)$.

3 метою оцінювання значущості різниці, за наявності нормального розподілу результатів досліджень, використовували t-критерій Стьюдента, а для показників, що мали розподіл, відмінний від нормального, використовували U-критерій Манна-Уітні (для незалежних груп) та критерій Вілкоксона (для залежних груп).

До дослідження було залучено пацієнтів 3 діагнозом ГПМК у правій гемосфрері головного мозку за ішемічним типом, ускладненим неглектом. Пацієнтів було розподілено на основну $(О Г, n=29)$ та контрольну групи (КГ, $\mathrm{n}=29)$. Критеріями виключення були: оцінки вище 3 за шкалою Scale of Contraversive pushing, бал за шкалою NIHSS вище 14. До КГ було включено 13 чоловіків та 16 жінок, а до ОГ 16 чоловіків та 13 жінок ( $p>0,05)$. Середній вік пацієнтів у КГ $69,3 \pm 9,77$ року, у ОГ $67,9 \pm 10,46$ року ( $p>0,05)$. На момент першого обстеження задовільний стан у КГ відмічено у п'яти пацієнтів, стан, близький до задовільного, у 12 пацієнтів, стан середньої важкості у шести пацієнтів, важкий стан також у шести пацієнтів. Серед пацієнтів ОГ задовільний стан відмічено у шести пацієнтів, стан, близький до задовільного, у 15 пацієнтів, стан середньої важкості у п'яти пацієнтів, важкий стан у трьох пацієнтів. Статистичний аналіз не встановив достовірної відмінності за цим розподілом ( $p>0,05)$.

Пацієнти КГ отримували програму фрізичної терапії, яка включала proprioceptive neuromuscular facilitation (PNF), тренування балансу, ерготерапевтичне втручання, вправи для розвитку дрібної моторики. Для пацієнтів ОГ було застосовано цілеорієнтоване втручання з урахуванням індивідуальних цілей кожного пацієнта, використовували PNF-терапію (патерни лопатки, верхньої кінцівки), вправи для відновлення балансу сидячи та стоячи при маніпуляції верхньою кінцівкою, рухову терапію вимушеним обмеженням (CIMT) та подвійні завдання.
Під час тренування пацієнтів з неглектом застосовували спеціальні стимулюючі та компенсуючі прийоми. Виконували стимуляцію ураженої сторони: зорову (розташування меблів), тактильну та рухову під час виконання завдань верхньою кінцівкою. Поступове залучення в простір з ураженої сторони через функціональні завдання (їжа чи предмети з ураженої сторони, паперові та комп'ютерні ігри тощо), яскраві ярлики (подушка, лінія).

Враховували нездатність до узагальнення пацієнт опрацьовував специфічні завдання в обстановці, максимально наближеній до його життєвої ситуації. На початку роботи йому робили пряму вказівку: робити ТАК. Згодом шляхом механічного запам'ятовування в результаті множинних повторень виконання завдання в природній обстановці поступово зменшували кількость підказок. Розподіляли функціональне завдання на невеликі компоненти. Систематично записували кількість нагадувань, фріксували всі епізоди необхідної допомоги під час виконання кожного компонента.

Наприкінці курсу використовували подвійні завдання, спрямовані на виконання двох дій одночасно. Метою подвійних завдань $\epsilon$ залучення в роботу обох півкуль головного мозку, покращення міжнейронних, формування нових нейронних зв'язків. При застосуванні цього принципу відбувається покращення когнітивних фуункцій: пам'яті, аналізу інформації, абстрактного мислення, асоціативного мислення, мовлення, візуального сприйняття, зменшення просторової дезорієнтації [2]. Використовували такі подвійні завдання, як маніпуляції верхньою кінцівкою і лічба, кидання м'яча і називання країн, силові навантаження. Перед початком втручання було зібрано і досліджено інформацію про житлові умови, діяльність пацієнта та можливість адаптації. Після цього разом з пацієнтом та його родичами складали цілі, які б відповідали їхнім запитам та були реалістичні до виконання.

Під час виконання завдань виконували велику кількість повторень для закріплення знань та навичок. Також кожного разу завдання ускладнювали, щоб зробити виклик пацієнту до прагнення досягання встановлених цілей [1].

Під час заняття динамічно змінювали діяльність пацієнта для кращої концентрації його уваги. Заняття планували так, щоб найбільше навантаження припадало на його середину. В обох групах терапію проводили п'ять днів на тиждень $14 \pm 4,2$ дня, а згодом у термін до трьох місяців тричі на тиждень. Перше тестування проводили на 14-й день. Через три місяці проводили повторне обстеження для всіх доменів. 
Відзначимо, що показники когнітивних функцій за шкалою МоСА у КГ та ОГ статистично не відрізнялися при першому обстеженні (табл. 1). Відповідно до заключних результатів, показники $\bar{x} \pm S$ пункту «зорово-конструктивні / виконавчі навички» у КГ становили 3,83 \pm 0,93 бала з можливих 5 ; при Ме $(25 \% ; 75 \%)$ на рівні $4(3 ; 4,5)$ бали. В ОГ показник був дещо вищим - 4,28 \pm \pm 1,16 бала; показники Ме (25 \%; 75 \%) становили $5(4 ; 5)$ балів. Відмінність між групами під час заключного обстеження була достовірною ( $><0,05)$. Щодо приросту $\bar{x}$, то у ОГ він становив 0,82 бала, а у КГ - 0,48 бала. Середнє значення ОГ було більшим на 0,45 бала, що становить 11,7 \% заключного показника КГ.

Водночас зміни у КГ не були достовірними порівняно $з$ початковими результатами ( $p>0,05)$, а в ОГ були статистично значущими ( $<<0,01)$.

На момент заключного обстеження середньостатистичні результати пункту «назви» у КГ були отримані на рівні $2,62 \pm 0,56$ бала з можливих 3; показники Ме (25\%; $75 \%$ ) встановлені на рівні 3 (2; 3) бали (див. табл. 1). У пацієнтів ОГ показник $\bar{x} \pm \mathrm{S}$ були дещо кращими і становили $2,79 \pm 0,49$ бала, а значення Ме $(25 \% ; 75 \%)-$ $3(3 ; 3)$ бали. Приріст $\bar{x}$ у ОГ був більшим $-0,48$ бала, а у КГ - 0,1 бала. Водночас зміни у КГ не були достовірними порівняно з початковими результатами ( $p>0,05)$, а в ОГ були статистично значущими $(p<0,01)$. Проте достовірної відмінності між заключними результатами груп не встановлено ( $p>0,05)$.

Показник «увага» за шкалою МоСА був статистично кращим у ОГ при порівнянні заключних показників (див. табл. 1). Значення Ме (25\%; $75 \%)$ у ОГ становили $3(2 ; 4)$ бали, а у КГ - 4 (3; $5)$ бали $(p<0,01)$. Середні значення зросли в ОГ з 2,69 \pm 1,14 бала до 4,24 \pm 1,30 бала, а у КГ з 2,83 \pm 1,04 бала до 3,31 \pm 1,37 бала при максимальній оцінці 6 балів. Відповідно приріст у групах був 1,55 та 0,48 бала. Водночас зміни у КГ не були достовірними порівняно 3 початковими результатами ( $>>0,05)$, а в ОГ були ( $p<0,01)$. Середнє значення ОГ було більшим на 0,93 бала, що становить $28,1 \%$ заключного показника КГ.

Аналіз заключних результатів пункту «мовлення» виявив показники $\bar{x} \pm S$ у КГ на рівні $1,93 \pm 0,65$ бала з можливих 3; при Ме (25\%; $75 \%)$ на рівні $2(1,5 ; 2)$ бали. В ОГ показник був дещо вищим - 2,07 $\pm 0,70$ бала, а показники Me (25\%; 75 \%) становили 2 (2; 3) бали. Різниця між результатами груп пацієнтів під час заключного обстеження не була достовірною ( $p>0,05)$. Зміни у КГ та ОГ були статистично значущими порівняно з початковими результатами $(p<0,05)$. Щодо приросту $\bar{x}$, то в ОГ він становив 0,38 бала, а у КГ - 0,10 бала.

Проведений статистичний аналіз результатів заключного обстеження когнітивних функцій за шкалою МоСА встановив середньостатистичні результати пункту «абстракція» у КГ на рівні 1,24 \pm 0,64 бала з можливих 2; показники Ме $(25 \% ; 75 \%)$ встановлені на рівні 1 (1; 2) бала. У пацієнтів ОГ значення $\bar{x} \pm \mathrm{S}$ були дещо кращими $-1,48 \pm 0,69$ бала, а значення Me $(25 \% ; 75 \%)$ були аналогічними і статистично не відрізнялися $(p>0,05)$. Приріст $\bar{x}$ у ОГ становив 0,55 бала, а у КГ - 0,17 бала. Зміни у КГ не були достовірними порівняно з початковими результатами ( $p>0,05)$, а в ОГ були статистично значущими ( $<<0,01)$. Відповідно до заключних результатів показників когнітивних фрункцій за шкалою МоСА, показники $\bar{x} \pm S$ пункту «відкладене повторення» у КГ становили $3,48 \pm 1,12$ бала з можливих 5 ; при Ме $(25 \% ; 75 \%)$ на рівні $3(3 ; 4,5)$ бали. В ОГ показник був дещо вищим $4,03 \pm 0,94$ бала; показники Ме (25 \%; 75 \%) $4(3,5 ; 5)$ бали. Відмінність між обстеженими групами пацієнтів під час заключного обстеження була достовірною $(p<0,05)$. Щодо приросту, то в ОГ він становив 1,17 бала, а у КГ - 0,86 бала. Середнє значення ОГ було більшим на 0,55 бала, що становить 15,8 \% заключного показника КГ. Зміни у КГ не були достовірними порівняно з початковими результатами (p >0,05), а в ОГ були статистично значущими ( $<<0,01)$. На момент заключного обстеження середньостатистичні результати пункту «орієнтація» у КГ були отримані на рівні 4,97 $\pm 1,02$ бала з можливих 6; показники Ме $(25 \% ; 75 \%)$ встановлені на рівні $5(4 ; 6)$ балів (див. табл. 1). У пацієнтів ОГ показники $\bar{x} \pm$ S були дещо кращими - 5,17 $\pm 0,76$ бала, a значення Ме $(25 \% ; 75 \%)-5(5 ; 6)$ балів. Приріст $\bar{x}$ у ОГ був більшим - 0,52 бала, а у КГ 0,21 бала. Зміни у КГ не були достовірними порівняно $з$ початковими результатами $(p>0,05)$, а в ОГ були статистично значущими $(p<0,01)$. Проте достовірної відмінності між заключними результатами груп не встановлено ( $p>0,05)$.

Загальний бал за шкалою МоСА був достовірно кращим у ОГ ( $p<0,05)$, середнє значення зросло на 5,48 бала і становило 24,07 \pm 4,09 бала. У КГ воно збільшилося на 2,41, тобто стало 21,38 \pm 4,8 бала. Так, середнє значення ОГ було більшим на 2,69 бала, що становить 12,6 \% заключного показника КГ. Зміни у КГ та ОГ були статистично значущими порівняно 3 початковими результатами $(p<0,01)$. Враховуючи, що показники шкали МоСА мали різний максимальний 
ТАБЛИЦЯ 1 - Початкові показники когнітивних функцій за шкалою МоСА у контрольній та основній групах пацієнтів

\begin{tabular}{|c|c|c|c|c|c|}
\hline \multirow{2}{*}{\multicolumn{2}{|c|}{ Пункт, \% }} & \multicolumn{2}{|c|}{ До проведення курсу реабілітації } & \multicolumn{2}{|c|}{ Після проведення курсу реабілітації } \\
\hline & & \multirow{2}{*}{$\frac{\kappa \Gamma(\mathbf{n}=\mathbf{2 9})}{3(3 ; 4)}$} & & & \\
\hline Зорово-конструктивні / виконавчі & $\operatorname{Me}(25 ; 75)$ & & $\frac{\mathrm{O}(\mathrm{n}=\mathbf{2 9})}{3(2,5 ; 5)}$ & $\begin{array}{c}\text { КГ(n = 29) } \\
4(3 ; 4,5)\end{array}$ & $\frac{O \Gamma(n=29)}{5(4 ; 5)^{*}}$ \\
\hline навички & $\bar{x} \pm S$ & $3,34 \pm 1,14$ & $3,45 \pm 1,38$ & $3,83 \pm 0,93$ & $4,28 \pm 1,16$ \\
\hline \multirow[t]{2}{*}{ Назви } & $\operatorname{Me}(25 ; 75)$ & $3(2 ; 3)$ & $3(2 ; 3)$ & $3(2 ; 3)$ & $3(3 ; 3)$ \\
\hline & $\bar{x} \pm S$ & $2,52 \pm 0,69$ & $2,31 \pm 0,89$ & $2,62 \pm 0,56$ & $2,79 \pm 0,49$ \\
\hline \multirow[t]{2}{*}{ Увага } & $\operatorname{Me}(25 ; 75)$ & $2(2 ; 3,5)$ & $3(2 ; 4)$ & $3(2 ; 4)$ & $4(3 ; 5)^{\star \star}$ \\
\hline & $\bar{x} \pm S$ & $2,83 \pm 1,04$ & $2,69 \pm 1,14$ & $3,31 \pm 1,37$ & $4,24 \pm 1,30$ \\
\hline \multirow[t]{2}{*}{ Мовлення } & $\operatorname{Me}(25 ; 75)$ & $2(1 ; 2)$ & $2(1 ; 2)$ & $2(1,5 ; 2)$ & $2(2 ; 3)$ \\
\hline & $\bar{x} \pm S$ & $1,83 \pm 0,71$ & $1,69 \pm 0,81$ & $1,93 \pm 0,65$ & $2,07 \pm 0,70$ \\
\hline \multirow[t]{2}{*}{ Абстракція } & $\operatorname{Me}(25 ; 75)$ & $1(1 ; 1)$ & $1(1 ; 1)$ & $1(1 ; 2)$ & $1(1 ; 2)$ \\
\hline & $\bar{x} \pm S$ & $1,07 \pm 0,59$ & $0,93 \pm 0,59$ & $1,24 \pm 0,64$ & $1,48 \pm 0,69$ \\
\hline \multirow[t]{2}{*}{ Відкладене повторення } & $\mathrm{Me}(25 ; 75)$ & $2(2 ; 3)$ & $3(2 ; 3)$ & $3(3 ; 4,5)$ & $4(3,5 ; 5)^{*}$ \\
\hline & $\bar{x} \pm S$ & $2,62 \pm 1,05$ & $2,86 \pm 0,88$ & $3,48 \pm 1,12$ & $4,03 \pm 0,94$ \\
\hline \multirow[t]{2}{*}{ Орієнтація } & $\mathrm{Me}(25 ; 75)$ & $5(4 ; 6)$ & $5(4 ; 5)$ & $5(4 ; 6)$ & $5(5 ; 6)$ \\
\hline & $\bar{x} \pm S$ & $4,76 \pm 1,15$ & $4,66 \pm 0,94$ & $4,97 \pm 1,02$ & $5,17 \pm 0,76$ \\
\hline \multirow[t]{2}{*}{ Загальний бал } & $\operatorname{Me}(25 ; 75)$ & $20(15 ; 23,5)$ & $19(14 ; 23)$ & $22(17,5 ; 25,5)$ & $25(21 ; 27,5)$ \\
\hline & $\bar{x} \pm S$ & $18,97 \pm 4,90$ & $18,59 \pm 5,01$ & $21,38 \pm 4,8$ & $24,07 \pm 4,09^{*}$ \\
\hline
\end{tabular}

* - різниця між показником статистично значуща порівняно з контрольною групою $(p<0,05)$; ${ }^{* *}-p<0,01$.

бал, необхідно представити заключні показники відносно максимальних оцінок (рис. 1).

Слід зазначити, що у ході аналізу отриманих показників було звернено увагу на те, що максимальний відсоток у ОГ та КГ отримав показник «назви» (93 та 87,3 \% відповідно). 3 іншого боку, мінімальний відсоток у ОГ отримав показник «мовлення» (69\%), а у КГ показник «увага» $(55,2 \%)$.

Окрім того, слід відмітити, що під час аналізу відносних значень показників найбільшу різницю отримано у показнику «увага» $-15,5 \%$. Мінімальна різниця між групами встановлена у показнику «орієнтація» - 3,4 \% (рис. 2). До- сить малу відмінність отримано й за показниками «мовлення» та «назви» - 4,7 та 5,7 \% відповідно.

Дискусія. Своєчасне діагностування та корекція неглекту $€$ надзвичайно важливими для повернення осіб у соціум після інсульту. Просторове ігнорування $€$ унікальним серед когнітивних наслідків захворювання: воно впливає на мислення, психічні, зорові та сенсорні фрункції, викликає симптоми, які впливають на тривимірні рухові фрункції [6]. U. Ungerstedt описував випадки повертання по колу при спробі рухатися уперед [28]. A. R. Riestra відмічав помилки повертання в осіб з неглектом [23], а інші учені

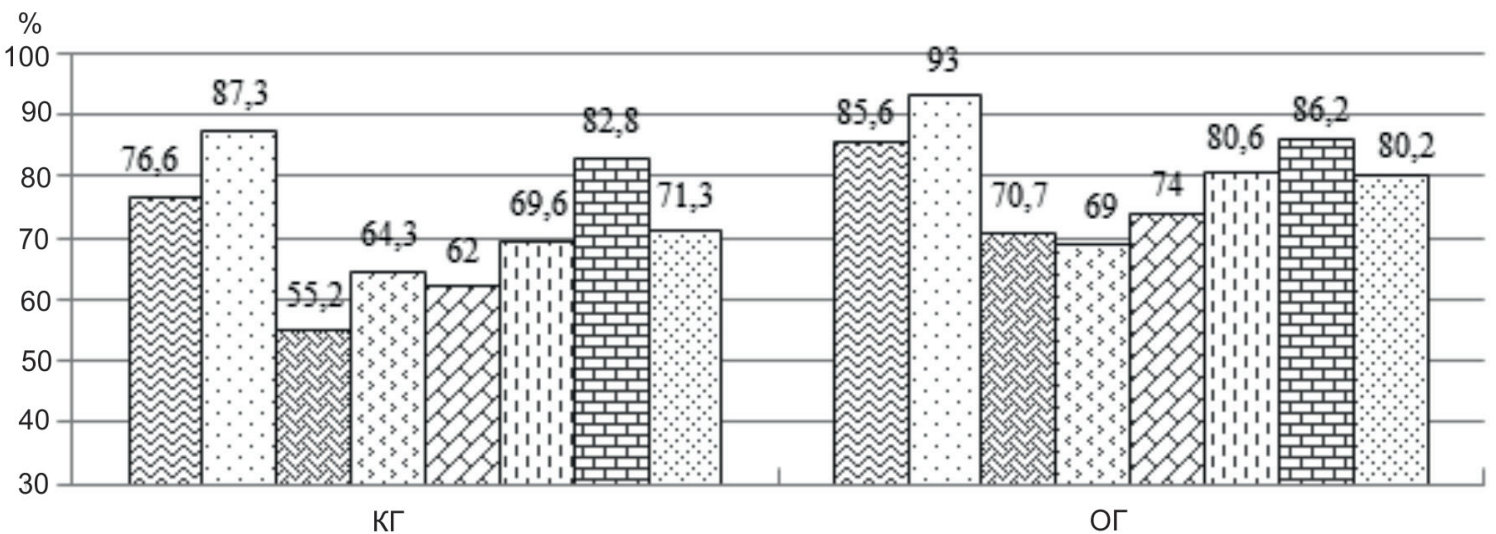

Рисунок 1 - Відносні заключні результати оцінювання показників за шкалою МоСА в основній та контрольній групах пацієнтів:

- зорово-конструктивні/виконавчі навички; $\because \cdot$ - назви; - увага; 2 - мовлення;

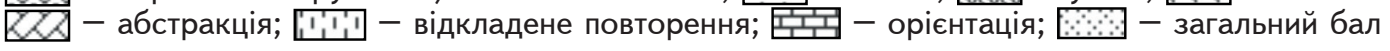




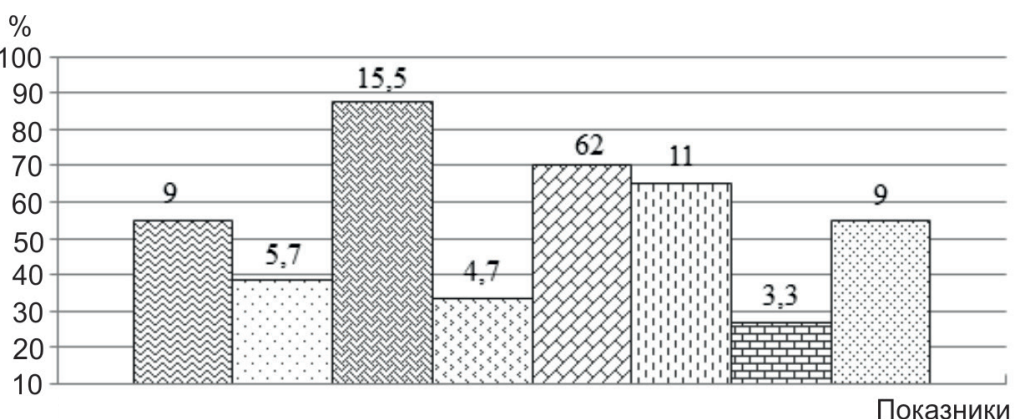

Рисунок 2 - Перевага основної групи у заключних відносних результатах оцінювання показників за шкалою МоСА:

쉉 - зорово-конструктивні/виконавчі навички; $\because \therefore-$ назви; - увага; ?3 мовлення; $Z Z Z$ - абстракція; 11. - відкла дене повторення; 臣無 - орієнтація; загальний бал

відмічали падіння, порушення постави та проблеми з безпекою в осіб, які перенесли ішемічний інсульт у правій півкулі головного мозку [26]. Це надзвичайно важливо, оскільки виявлено у шість разів більший ризик падінь у людей з просторовим ігноруванням [19].

Y. Kimura et al. [16] вивчали вплив одностороннього просторового ігнорування 3 іншими когнітивними порушеннями або без них на самостійне відновлення ходьби в осіб з інсультом. Учені дійшли висновку, що наявність одностороннього просторового ігнорування без інших когнітивних порушень не $є$ суттєвим фрактором для відновлення самостійної ходьби. У поєднанні $з$ іншими когнітивними порушеннями одностороннє просторове ігнорування стає сильним негативним фрактором.

T. Ogourtsova et al. [21] у своєму дослідженні висвітлили вплив неглекту на відновлення рухових та навігаційних навичок, необхідних для мобільності у громаді. Вони виявили, що наявність неглекту змінює цілеспрямований рух в умовах різних когнітивних/перцептивних потреб. В умовах занурення у 3D-середовище віртуальної реальності виявлено більші середні похибки кінцевих точок для лівосторонніх цілей (запам'ятовування та умови зміщення) та збільшений час реагування при переорієнтації цілей. Таким чином, дефріцит уваги та сприйняття, пов'язаний з просторовим ігноруванням, змінює навигаційні здібності в умовах, що змінюються, та у діях, що відтворюються пам'яттю, незалежно від дефріциту рухового апарату після інсульту.

G. Aravind et al. [3] виявили, що зорово-просторове ігнорування погіршує контроль руху в осіб після інсульту, що може вплинути на їх здатність безпечно уникати рухомих предметів під час ходьби. Ученими були досліджені зміни курсу та орієнтації голови у просторі для уникнення перешкод, що наближаються з різних напрямків, та переорієнтації руху пацієнта на кінцеву мету.

Для пацієнтів 3 неглектом відхилення на ту саму сторону, що і перешкода, було безпечною стратегією уникнення діагональних перешкод, а відхилення на протилежну сторону призводило до випадкових зіткнень. Учасники VSN+ відхилялись іпсилезіонально, демонструючи стратегії однакової та протилежної сторін щодо іпсілезіональних та контралезійних перешкод відповідно. Загалом, пацієнти з неглектом демонстрували погане цільове спрямування ходьби, затримку при початку зміни курсу, менші максимальні середньобічні відхилення та більші помилки у вирівнюванні цілі порівняно з пацієнтами без неглекту.

Останніми дослідженнями виявлено, що особи 3 деоріцитом сприйняття та уваги через зорово-просторове ігнорування після інсульту ризикують зіткнутися під час ходьби з рухомою перешкодою. G. Aravind et al. [2] зазначають, що подвійне завдання у пацієнтів з неглектом спричинило погіршення рухового контролю (більше зіткнень, затримка часу реагування та менші мінімальні відстані) та когнітивні показники (вищий рівень помилок). Тобто відволікання уваги під час виконання подвійного завдання знижує есрективність уникнення перешкод та призводить до більшого ризику зіткнень. Навпаки, особи без неглекту робили більше когнітивних помилок, але успішно рухалися у заданому напрямку.

Пересування серед людей можуть бути складними для тих, хто пережив інсульт. Той фракт, що ходьба часто вимагає одночасного виконання різноманітних завдань, призводить до погіршення продуктивності одного чи обох завдань. A. Deblock-Bellamy [11] перевірено різницю у здатності виконувати подвійне завдання під час руху між особами, які відновилися після інсульту, та здоровими дорослими такого самого віку. Оглянувши існуючу літературу з високою методологічною якістю про когнітивно-рухові фрункції подвійного завдання у чотирьох базах даних (MEDLINE, CINAHL, EMBASE та PEDro), встановлено, що незважаючи на неоднорідні результати в ході досліджень, найбільші проблеми виникали в осіб після інсульту при уникненні перешкод під час ходьби. На результат також впливав характер когнітивного завдання. 
Двофракторний аналіз медичних карток з 10 випадково обраних лікарень гострої допомоги в Онтаріо (Канада), проведений A. Menon-Nair et al. [18], виявив значний зв'язок між виразністю когнітивних порушень і тяжкістю рухових дефріцитів верхніх кінцівок у осіб із зорово-просторовим ігноруванням після інсульту.

Ігри на основі віртуальної реальності (VR) $\epsilon$ привабливим способом забезпечити залучення пацієнта, мотивацію на адаптоване середовище для реабілітації після інсульту [10].

J. A. Semrau et al. [25] виявили, що пацієнти із зорово-просторовим ігноруванням у $100 \%$ випадків мали порушення кінестезії, тоді як пацієнти без неглекту лише у $59 \%$ виявляли наявність кінестетичного дефріциту. Однак його наявність не обов'язково завжди свідчить про наявність зорово-просторового ігнорування. Дослідники підкреслюють важливість оцінки та лікування кінестетичного дефріциту після інсульту, особливо у пацієнтів із неглектом.

T. Linden [17] досліджував поширеність зорового ігнорування та його зв'язок з когнітивними порушеннями та деменцією у пацієнтів літнього віку через 20 місяців після інсульту. Когнітивні порушення були удвічі частішими у пацієнтів із неглектом, ніж у пацієнтів без нього, і втричі частіші, коли ігнорування було комплексним. Найчастіше воно було пов'язане з апраксією, порушенням полів зору та попереднім інсультом.

\section{Література}

1. Камаева ОВ, Монро П, Буракова ЗФ, Зычкова ОБ, Иванова АА, Сорокоумов ВА, Тищенко МЕ. Мультидисциплинарный подход в ведении и ранней реабилитации неврологических больных [Multidisciplinary approach to the management and early rehabilitation of neurological patients]: методическое пособие. Санкт-Петербург. 2003. 42 c.

2. Aravind G, Lamontagne A. Dual tasking negatively impacts obstacle avoidance abilities in post-stroke individuals with visuospatial neglect: Task complexity matters! Restor Neurol Neurosci. 2017;35(4):423-436. doi: 10.3233/ RNN-160709. PMID: 28697573.

3. Aravind G, Lamontagne A. Effect of visuospatial neglect on spatial navigation and heading after stroke. Ann Phys Rehabil Med. 2018 Jul;61(4):197-206. doi: 10.1016/j.rehab.2017.05.002. Epub 2017 Jun 9. PMID: 28602491.

4. Azouvi P, Olivier S, de Montety G, et al. Behavioral Assessment of Unilateral Neglect: study of the psychometric properties of the Catherine Bergego Scale. Arch Phys Med Rehabil.2003; 84:51-57.

5. Barrett AM. Perceptual-attentional "where" and motor-intentional "aiming" spatial bias. In: Chatterjee A, Coslett HB, editors. The roots of cognitive neuroscience: behavioral neurology and neuropsychology. New York: Oxford University Press. 2013.

6. Barrett AM, Houston KE. Update on the Clinical Approach to Spatial Neglect. Curr Neurol Neurosci Rep. 2019 Apr 4;19(5):25. doi: 10.1007/s11910019-0940-0. PMID: 30949868; PMCID: PMC6733261.

7. Chen $P$, Hreha K, Kong Y, BarrettAM. Impactofspatial neglectin stroke rehabilitation: evidence from the setting of an inpatient rehabilitation facility. Arch Phys Med Rehabil. 2015;96(8):1458-66.

8. Chen P, Pitteri M, Gillen G, Ayyala H. Ask the experts how to treat individuals with spatial neglect: a survey study. Disabil Rehabil. 2018 Nov;
Важкий неглект був пов'язаний $з$ деменцією, амнезією та порушенням полів зору. Учені наполягають на підвищеній пильності до порушень просторової уваги при лікуванні пацієнтів з деменцією та іншими когнітивними порушеннями після інсульту.

Висновки. Синдром неглекту - це порушення сприйняття простору і схеми свого тіла, виражений в ігноруванні половини тіла і/чи простору зі сторони, протилежної ураженій півкулі головного мозку, а також інформації, що надходить з цієї сторони. Внаслідок неглекту у пацієнтів за тестом МоСА було виявлено проблеми з зорово-конструктивними виконавчими навичками, пам'яттю, увагою, абстракцією та орієнтацією. Загальний бал становив $20(15 ; 23,5)$ у КГ та $19(14 ; 23)$ у ОГ з 30 можливих. Результати важкості неглекту визначали цілі фрізичної терапії та ерготерапії осіб, які перенесли інсульт. Програма реабілітації була спрямована на відновлення рухових та когнітивних навичок. Найбільшу увагу приділяли верхній кінцівці. Під впливом запропонованої програми наприкінці курсу отримані позитивні зміни за шкалою МоСА до $22(17,5 ; 25,5)$ у КГ та $25(21 ; 27,5)$ у ОГ.

Перспективи подальших досліджень передбачають подальше визначення доцільності застосування запропонованих втручань у осіб з правопівкульним ішемічним інсультом, ускладненим неглектом.

40(22):2677-2691. doi: 10.1080/09638288.2017.1347720. Epub 2017 Jul 11. PMID: 28697652.

9. Chen P, Ward I, Khan U, Liu Y, Hreha K. Spatial neglect hinders success of inpatient rehabilitation in individuals with traumatic brain injury: a retrospective study. Neurorehabil Neural Repair. 2016;30(5):451-60. The syndrome of spatial neglect affects people with many kinds of right brain disorders, adversely affecting outcomes.

10. Choi HS, Shin WS, Bang DH. Application of digital practice to improve head movement, visual perception and activities of daily living for subacute stroke patients with unilateral spatial neglect: Preliminary results of a single-blinded, randomized controlled trial. Medicine (Baltimore). 2021 Feb 12;100(6):e24637. doi: 10.1097/MD.0000000000024637. PMID: 33578583 ; PMCID: PMC7886475.

11. Deblock-Bellamy A, Lamontagne A, Blanchette AK. Cognitive-Locomotor Dual-Task Interference in Stroke Survivors and the Influence of the Tasks: A Systematic Review. Front Neurol. 2020 Aug 18;11:882. doi: 10.3389/ fneur.2020.00882. PMID: 33013625; PMCID: PMC7461874.

12. Edwards DF, Hahn MG, Baum CM, Perlmutter MS, Sheedy C, Dromerick AW. Screening patients with stroke for rehabilitation needs: validation of the post-stroke rehabilitation guidelines. Neurorehabil Neural Repair. 2006;20(1):42-8

13. Esposito E, Shekhtman G, Chen P. Prevalence of spatial neglect post-stroke: a systematic review. Ann Phys Rehabil Med. 2020 Nov 24:S18770657(20)30218-9. doi: 10.1016/j.rehab.2020.10.010. Epub ahead of print. PMID: 33246185.

14. Goedert KM, Chen P, Boston RC, Foundas AL, Barrett AM. Presence of motor-intentional aiming deficit predicts functional improvement of spatial neglect with prism adaptation. Neurorehabil Neural Repair. 2014;28(5):483-92. 
15. Goedert KM, Chen P, Botticello A, Masmela JR, Adler U, Barrett AM. Psychometric evaluation of neglect assessment reveals motorexploratory predictor of functional disability in acute-stage spatial neglect. Arch Phys Med Rehabil. 2012:93(1):137-2.

16. Kimura $Y$, Yamada M, Ishiyama D, Nishio N, Kunieda $Y$, Koyama S, Sato A, Otobe Y, Ohji S, Suzuki M, Ogawa H, Ito D, Ichikawa T, Hamanaka K, Tanaka N, Muroh Y. Impact of unilateral spatial neglect with or without other cognitive impairments on independent gait recovery in stroke survivors. J Rehabil Med. 2019 Jan 1;51(1):26-31. doi: 10.2340/16501977-2503. PMID: 30406267.

17. Linden T, Samuelsson H, Skoog I, Blomstrand C. Visual neglect and cognitive impairment in elderly patients late after stroke. Acta Neurol Scand. 2005 Mar;111(3):163-8. doi: 10.1111/j.1600-0404.2005.00391.x. PMID: 15691284 .

18. Menon-Nair A, Korner-Bitensky N, Wood-Dauphinee S, Robertson E Assessment of unilateral spatial neglect post stroke in Canadian acute care hospitals: are we neglecting neglect? Clin Rehabil. 2006 Jul;20(7):623-34. doi: 10.1191/0269215506cr9740a. PMID: 16894806

19. Nijboer TC, Kollen BJ, Kwakkel G. The impact of recovery of visuo-spatial neglect on motor recovery of the upper paretic limb after stroke. PLoS One. 2014;9(6):e100584.

20. Norrving $B$, at al. on behalf of the Action Plan for Stroke in Europe Wfoiidng Group. Action Plan for Stroke in Europe 2018-2030. Eumpean Stroke Journal Ш. 3(4) 309-336.C 2018 European Stroke Organisation 2018.

21. Ogourtsova T, Archambault PS, Lamontagne A. Post-stroke unilateral spatial neglect: virtual reality-based navigation and detection tasks reveal lateralized and non-lateralized deficits in tasks of varying perceptual and cognitive demands. J Neuroeng Rehabil. 2018 Apr 23;15(1):34. doi: 10.1186/s12984018-0374-y. PMID: 29685145; PMCID: PMC5913876.

22. Plummer $P$, Morris ME, Dunai J. Assessment of unilateral neglect. Phys Ther. 2003 Aug:83(8):732-40. PMID: 12882614

23. Riestra AR, Barrett AM. Rehabilitation of spatial neglect. Handb Clin Neurol. 2013;110:347-55.

24. Saevarsson S, Eger S, Gutierrez-Herrera M. Neglected premotor neglect. Front Hum Neurosci. 2014;8:778.

25. Semrau JA, Wang JC, Herter TM, Scott SH, Dukelow SP. Relationship between visuospatial neglect and kinesthetic deficits after stroke. Neurorehabil Neural Repair. 2015 May;29(4):318-28. doi: 10.1177/1545968314545173. Epub 2014 Aug 12. PMID: 25118184.

26. Shinsha N, Ishigami S. Rehabilitation approach to patients with unilateral spatial neglect. Top Stroke Rehabil. 1999;6(1):1-14

27. Stevens $E$, McKevitt $C$, Emmett $E$, et al. The burden of stroke in Europe.London: Stroke Alliance for Europe (SAFE), www.strokeeurope.eu/downloadsДheBurdenOfStrokelnEurope Report.pdf (2017, accessed19 April 2018).

28. Ungerstedt U. Striatal dopamine release after amphetamine or nerve degeneration revealed by rotational behaviour. Acta Physiol Scand Suppl. 1971:367:49-68

29. United Nations Division for Social PoUcy and Development.Convention on the Rights of Persons with Disabilities (CRPD),www.un.org/development desa/disabilities/convention-on-therights-of-persons-with-disabilities.html (accessed 19 April 2018)

30. Worid Health Organization. Rehabilitation 2030: a call for action www.whaint/disabilities/care/rehab-2030/ en/ (2017, accessed 24 April 2018).

yura.dido.1994@gmail.com

olena.dulo@uzhnu.edu.ua

Надійшла 11.05.2021 